\title{
PENGAWET MAKANAN: Sebuah Bahasan untuk Penetapan Halalan Toyyiban
}

\author{
Elok Kamilah Hayati
}

Jurusan Kimia Fakultas Sains dan Teknologi UIN Maulana Malik Ibrahim Male Jalan Gajayana 50 Malang, Telp. (0341) 558933 e-mail: eloksunardji@yahoo.co:

\section{Abstract}

As the primary needs of human being, food we consume must be halal and good as prescribed by Muslim law which is explicitly stated in Quran and Hadith. Deciding the food is halal or not can be detected from its benefit and disadvantage, and also from its processing. The development of food industry has brought better change both qualitatively and quantitatively on the food. This caused a significant improvement on food ingredients such as preservative and texture of the food. The consumer needs fresh, cheap, and easy-serving as the consequence of practical life. The high demand on economic interest and the complexity of food causes the increase of chemical substance as the preservative, such as formalin. The use of preservative that is to preserve foodstuffs against decay is very danger as it brings negative effect to our health. Therefore, the idea of back to nature which promotes the optimal use of natural food must be highly recommended. This can, physiologically, be received easily to our body.

Key words: food, halal and good, preservative 


\section{Pendahuluan}

Makanan yang bersifat halalan yang berarti "lepas" atau "tidak terikat". Secara etimologi kata halalan berarti hal-hal yang boleh dan dapat dilakukan karena bebas atau tidak terikat dengan ketentuan-ketentuan yang melarangnya. Atau diartikan sebagai segala sesuatu yang bebas dari bahaya baik untuk dimensi kehidupan duniawi maupun ukhrawi. Sedangkan kata thayyib berarti lezat, baik, sehat, menentramkan dan paling utama. Dalam konteks makanan atau minuman kata thayyib berarti makanan yang tidak kotor dari segi zatnya atau rusak (kadaluarsa), atau bercampur benda najis. Ada juga yang mengartikan sebagai makanan atau minuman yang mengundang selera bagi yang akan mengkonsumsinya dan tidak membahayakan fisik serta akalnya. Juga ada yang mengartikan sebagai makanan yang sehat, proporsional dan aman.

Makanan yang halal pasti akan bersifat toyyib, akan tetepi makan yang toyyib belum tentu besifat halal. Makanan yang bersifat aman artinya tidak menyebabkan penyakit, dengan kata lain aman secara duniawi dan ukhrawi. Keamanan pangan (food safety) ini secara implisit dinyatakan dalam al Quran:

"Dan makanlah makanan yang halal lagi baik dari apa yang Allah telah rizkikan kepadamu, dan bertawakallah keada Allah dan kamu beriman kepada-Nya." (QS. al Maidah: 88)

Ayat ini memerintahkan manusia untuk mengkonsumsi makanan atau minuman dalam konteks ketakwaan pada saat menjalankan perintah konsumsi makanan. Supaya manusia berupaya untuk menghindari makanan atau minuman yang mengakibatkan siksa dan terganggunya rasa aman.

Masalah pangan selalu mendesak apabila ditambah dengan masalah laju kenaikan penduduk. Dalam produksi, penggandaan, dan konsumsi, bahan pangan banyak mengalami perubahan, baik yang diharapkan atau tidak. Perubahan tersebutsebagian besar berasal dari reaksi kimia dan bahanbahan kimia. Harapannya perubahan bahan pangan tersebut hendaknya tidak bertentangan dengan ajaran Islam, jangan sampai menjadikan yang 
halal menjadi haram dan yang haram menjadi halal.

Produk halal tidak saja memenuhi kebutuhan aspek syar ` $\mathrm{i}$, melainkan juga terjaga dari segi kualitas dan higienisnya. Itu sebabnya produk halal amą didambakan dan dicari konsumen Muslim di dunia, karena bagi konsumen Muslim, panduannya sudah jelas sebagaiman dalam al Quran surat al Baqarah, ayat 168:

"Hai sekalian manusia, makanlah yang halal lagi baik dari apa yang terdapat di bumi, dan janganlah kamu mengikuti langkah-langkah syaitan; karena sesungguhnya syaitan itu adalah musuh yang nyata bagimu" (QS. al Baqarah: 168).

Setelah Allah menjelaskan bahwa tiada Tuhan kecuali Dia, dan Dia yang menjadikan serta member rizki kepada semua makhluk-Nya, maka dalam ayat ini Allah memperbolehkan mereka makan semua makanan yang ada di bumi, yaitu yang halal dan baik, lezat dan tidak mengandung bahaya bagi badan, atau akal dan urat syaraf. Selain itu Allah melarang manusia mengikuti bisikan setan yang sengaja akan menyesatkan manusia dari tuntunan Allah dengan cara mengharamkan yang halal dan menghalalkan yang diharamkan Allah (Bhreisy dan Bahreisy, 2002: 316). Halal haram, selain ditinjau dari manfaat, kerugian dari bahan pangan tersebut, dapat pula ditinjau dari segi pemerolehan bahan tersebut, bisa jadi secara manfaat bahan pangan tersebut adalah halal, akan tetapi di peroleh dari sumber yang bersifat haram, maka bahan pangan tersebut bersifat haram. Perkembangan industri pangan yang memberikan perubahan baik secara kualitatif atau kuantitatif pada makanan menyebabkan perkembangan dalam bahan makanan maju pesat, baik itu untuk pengawet, perasa, tekstur atau warna dari makanan. Kita tidak dapat menghindari dari perkembangan teknologi tersebut, penelitian-penelitian yang dilakukkan di negara maju akan mempengaruhi dan merubah keadaan sosial. Konsumen membutuhkan makanan yangsegar, murah dan mudah disajikan sebagai tuntutan zaman yang makin praktis. Teknologi yang bertambah maju makin meningkatkan bahan-bahan kimia yang ditambahkan pada makanan untuk memenuhi kebutuhan konsumen. Menurut hasil penelitian terdapat 2.500 variasi kimia. 
Bahan-bahan tambahan tersebut dapat mempengaruhi kualitas bahan makanan, penambahan bahan tambahan tersebut dapat memperpanjang waktu kadaluarsa bahan pangan, meningkatkan aroma dan penampilan bahan pangan. Zataditif adalah substansi atau campuran dari substansi selain dari makanan dasar (karbohidrat) yang ada dalam makanan, sebagai akibat dari aspek produk, proses, penyimpana dan packing. Adapun kegunaan dari zat aditif adalah melindungi nutrisi makanan, dan harga produksi lebih murah. Yang termasuk dalam zat aditif adalah pewarna, penyedap rasa dan aroma, antioksida, pengawet, pengemulsi, anti penggumpal dan lain-lain.

Mengkonsumsi, memproduksi makanan/minuman yang halalan thayyiban sangat erat kaitannya dengan masalah imandan takwa. Keterikatan i telah Allah SWT tegaskan dalam surat al Maidah: 88. Selain kita i perintahkan untuk memakan makanan yang halal, ayat tersebut juga 1: emerintahkan untuk kita berhati hati memilih makanan juga bagimana :a mendapatkannya, sedangkan bagi produsen masalah keimanan dan ! cakwaan ini dapat dihubungkan dengan bagaimana makanan tersebut (i) buat, karena makanan ini nantinya dikonsumsi oleh masyarakat luas, sehingga tanggung jawab secara moral pada diri sendiri dan lingkungan serta pada Allah menjadi hal yang sangat utama.

Ada beberapa alasan produsen makanan melakukan pengawetan pada makanan. Salah satunya karena daya tahan hampir sebagian besar makanan sangat terbatas dan mudah rusak (perishable). Dengan pengawetan, makanan bisa disimpan berhari-hari, bahkan berbulan-bulan dan sangat menguntungkan produsen. Selain itu, beberapa zat pengawet berfungsi sebagai penambah daya tarik makanan itu sendiri. Seperti penambahan kalium nitrit agar olahan daging tampak berwarna merah segar, yang akan menarik konsumen untuk membeli produk olahan tersebut (Boedihardjo dalam Widianti, 2007). Pada umumnya bahan sintetik mempunyai kelebihan yaitu lebih pekat, lebih murah. Akan tapi, penambahan bahan pengawet ini mempunyai kelemahan yaitu sering terjadi ketidaksempurnaan proses sehingga mengandung zat-zat yang berbahaya bagi kesehatan dan kadang bersifat karsinogenik yang dapat meragsang terjadinya penyakit kanker pada manusia. 
Akhir-akhir ini, pelaku konsumen lebih cenderung menggunakan suatu bahan tambahan yang murah dan menghasilkan produksi yang banyak, dibandingkan dengan bahan tambahan kimia yang aman bagi tubuh. Mereka cenderung menggunakan bahan sintesis dibandingkan menggunakan bahan alami. Batasan-batasan tersebut dilanggar oleh oknumoknum yang ingin mengambil keuntungan produksi secara cepat. Melalui tulisan ini, penulis ingin mengajak untuk mengetahui pengawet yang bisa digunakan untuk proses pengawetan makanan yang alami serta toyibban. Makanan yang halal akan bersifat toyyiban, tetapi makanan toyyiban belum tentu bersifat halal.

\section{Bahan Pengawet}

Berdasarkan firman Allah dalam surat al Baqarah 172:

"Hai orang-orang yang beriman, makanlah di antara rezki yang baik-baik yang Kami berikan kepadamu dan bersyukurlah kepada Allah, jika benar-benar kepada-Nya kamu menyembah" (QS. al Baqaroh: 172).

Makna ayat diatas menyebutkan bahwa semua yang tidak diharamkan oleh agama adalah bersifat halal, tak terkecuali dengan pengawet yang digunakan sebagai bahan tambahan makan. Pengawet makanan yang bersumber dari barang yang haram akan bersifat haram, bahan pengawetvmakanan apabila berupa hewan yanghalal jika disembelih dengan tidak menyebut nama Allah pun bersifat haram.

Proses pengawetan telah ada sejak peradaban manusia. Orang kuno menggunakan bahan yang ada di alam untuk mengawetkan bahan pangan mereka, hal ini dilakukkan secara turun menurun. Penggunaan asap telah digunakan untuk proses pengawetan daging, ikan dan jagung. Demikian pula pengawetan dengan garam, asam dan gula telah dikenal sejak dulu kala. $\mathrm{Di}$ abad modern mulai dikenal penggunaan bahan pengawet mengunakan senyawaan kimia sintetis dengan tujuan untuk mempertahankan pangan dari gangguan mikroba, sehingga bahan pangan lebih awet dan tidak merubah tampilan dari bahan pangan tersebut. 
Bahan pengawet umumnya digunakan untuk mengawetkan pangan yang mempunyai sifat mudah rusak. Bahan ini dapat menghambat atau memperlambat proses fermentasi, pengasaman, atau penguraian yang disebabkan oleh mikroba. Akan tetapi tidakjarang produsen menggunakannya pada bahan pangan yang relatif awet dengan tujuan untuk memperpanjang masa simpan atau memperbaiki tekstur (Cahyadi, 2008: 5).

Salah satu mikro organisme yang menyebabkan rusaknya mutu atau kualitas bahan pangan adalah mikroba. Mikroba membawa penyakit sehingga akan menyebabkan suatu infeksi. Teknologi pangan membuat suatu senyawa kimia antimikroba, sehingga makanan tidak mudah rusak. Untuk mencegah adanya mikroba dalam makanan dapat dilakukan dengan pemanasan, pengeringan, fermentasi atau penambahan senyawasenyawa kimia. Penambahan garam nitrat atau nitrit cenderung berbahaya. Penambahan nitrit atau nitrat digunakan dalam proses curing daging untuk memperoleh warna yang baik dan mencegah pertumbuhan mikroba. Selain itu dewasa ini cukup marak penambahan formalin yang merupakan larutan organik bersifat karsinogenik yang digunakan sebagai pengawet makanan.

Pada massa sekarang ini, antimikroba pada makanan digunakan untuk pengawet dan mempunyai peran signifikan dalam memproduksi suplai makanan.

Ada beberapa faktor yang harus diperhatikan terkait senyawa sebagai antimikroba:

a. Mengetahui spektrum mikroba

b. Sifat kimia dan hasil dari anti mikroba harus diketahui

c. Produk makanan harus diketahui (nilai pka, kelarutan, $\mathrm{pH}$ dan lain lain)

Permenkes No 722/MenKes/Per/ IX/88 telah mengatur bahan-bahan yang boleh digunakan. Bahan-bahan tersebut bisa untuk mengawetkan, mewarnai, maupun mengemulsi, memantapkan, dan mengentalkan. Bahan pengawet yang banyak di jual di masyarakat dan digunakan untuk mengawetkan berbagai bahan pangan salah satunya adalah asam benzoat, benzoat ini umumnya terdapat dalam bentuk garam natrium dan kaliumm 
benzoat yang sifatnya mudah larut. Benzoat sering digunakan untuk mengawetkan berbagai pangan dan minuman, seperrti sari buah, minuman ringan, saus tomat, saus sambal, selai jeli, manisan, kecap dan lain-lain (Cahyadi, 2008: 5).

Jenis pengawet benzoat merupakan salah satu bahan-bahan yang direkomendasikan oleh Badan POM sesuai dengan Permenkes No 722/ MenKes/Per/ IX/88, untuk digunakan sebagai pengawet, karenya jenis pengawet ini tergolong bersifat halal. Akan tetapi pengawet benzoat ini diindikasikan menimbulkan efek negatif jika dikonsumsi oleh individu tertentu misalnya yang alergi atau jika digunakan secara berlebihan. Bahan pengawet ini dapat menghambat pertumbuhan bakteri penghasil toksin (racun), bakteri spora dan bakteri bukan pembusuk. Senyawa ini dapat mempengaruhi rasa.

Bahan makanan atau minuman yang diberi benzoat dapat memberikan kesan aroma fenol, yaitu seperti aroma obat cair. Asam benzoat digunakan untuk mengawetkan minuman ringan, minuman anggur, saus sari buah, sirup, dan ikan asin. Bahan ini bisa menyebabkan dampak negatif pada penderita asma dan bagi orang yang peka terhadap aspirin. Kalsium Benzoat bisa memicu terjadinya serangan asma (Jusuf, 2009). Sehingga benzoat cenderung bersifat sebagai pengawet yang bersifat mubah/boleh dalam batas ambang tertentu, bahkan bisa jadi dengan penggunaan berlebih dan merugikan tersebut benzoate bersifat haram, karena menimbulkan kemudorotan dibandingkan manfaatnya.

Umumnya senyawa-senyawa pengawet sintesis tergolong dalam kelompok yang bersifat mubah atau boleh, karena cenderung menyebabkan efek samping jika digunakan secara berlebih. Penggunaan pengawet dalam pangan harus tepat, baik jenis maupun dosisnya. Suatu bahan mungkin akan bersifat efektif untuk mengawetkan pangan tertentu akan tetapi tidak untuk mengawetkan pangan yang lain, sehingga mikroba perusak yang akan dihambat pertumbuhannya juga berbeda. Pada saat ini, masih banyak penggunaan bahan-bahan pengawet yang dilarang untuk digunakan dalam pangan dan berbahaya bagi kesehatan, seperti boraks dan formalin. Badan 
POM-MUI pun telah memfatwakan pengawet borak dan formalin bersifat haram untuk dikonsumsi dan digunakan sebagai pengawet dalam pangan.

Kecenderungan back to nature mengoptimalkan bahan-bahan alam untuk digunakan sebagai pengawet makanan alami. Penelitian mengenai potensi pengawet alami yang dikembangkan dari tanaman rempah (seperti jahe, kayu manis, andaliman, daun salam dan sebagainya) maupun dari produk hewani (seperti lisozim, laktoperoksidase, kitosan dan sebagainya) sendiri sebenarnya telah banyak dilakukan di berbagai perguruan tinggi di Indonesia. Akan tetapi, penggunaan bahan antimikroba kimia, di lingkungan masyarakat (produsen) lebih banyak digunakan dalam produk pangan, mengingat hasil yang lëbih baik sebagai pengawet dan biaya yang relatif lebih murah.

\section{Sifat Antimikroba Bahan Pengawet}

Senyawa antimikroba adalah bahan pengawet yang berfungsi untuk menghambat kerusakan pangan akibataktivitas mikroba. Sejarah penggunaan pengawet didalam bahan pangan sendiri bermula dari penggunaan garam, asap dan asam (proses fermentasi) untuk mengawetkan pangan. Sejumlah bahan antimikroba kemudian dikembangkan dengan tujuan untuk menghambat atau membunuh mikroba pembusuk (penyebab kerusakan pangan) dan mikroba patogen (penyebab keracunan pangan) (Syamsir, 2007).

Pemilihan awal suatu senyawa antimikroba umumnya didasarkan atas spektrum antimikrobanya. Senyawa antimikroba yang diinginkan adalah yang luas, meskipun hal ini sulit dicapai. Beberapa senyawa mempunyai kemampuan untuk menghambat beberapa jenis mikroba, tetapi penghambatan suatu mikroba kadang-kadang menyebabkan mikroba lain didalam produk tersebut menjadi dominan. Oleh karena itu, senyawa antimikroba untuk suatu produk harus besifat aktif untuk semua mikroba yang tidak diinginkan didalam produk itu (Syamsir, 2007: 1-2).

Mekanisme kerja antimikroba secara umum menghambat keutuhan permeabilitas dinding sel, menghambat sistem genetik, menghambat kerja enzim, peningkatan nutrien esensial (Cahyadi, 2008: 8-9) 


\section{Menghambat Sintesis Dinding Sel Bakteri}

Bahan kimia tidak perlu masuk kedalam sel untuk menghambat pertumbuhan, reaksi yang terjadi pada dinding sel atau membran sel dapat mengubah permeabilitas sel. Hal ini dapat mengganggu atau menghalangi jalannya nutrien masuk kedalam sel, dan mengganggu keluarnya zat-zat penyusun sel dan metabolit dari dalam sel. Kerusakan membran sel dapat terjadi karena reaksi antara bahan pengawet atau senyawa antimikroba dengan sisi aktif atau larutnya senyawa lipid. Dinding sel merupakan senyawa yang kompleks, karena itu senyawa kimia dapat bercampur dengan penyusun dinding sel sehingga akan mempengaruhi dinding sel dengan jalan mempengaruhi penghambatan polimerisasi penyusun dinding sel. Apabila berkembang lebih lanjut maka akibatnya kebutuhan sel tidak dapat terpenuhi dengan baik.

\section{Menghambat Sistem Genetik}

Dalam hal ini senyawa antimikroba/bahan kimia masuk ke dalam sel. Beberapa senyawa kimia dapat berkombinasi atau menyerang ribosom dan menghambat sintesis protein. Jika gen-gen dipengaruhi oleh senyawa antimikroba atau bahan kimia maka sintesa enzim yang mengontrol gen akan dihambat.

\section{Penghambatan Enzim}

Perubahan $\mathrm{pH}$ yang mencolok, $\mathrm{pH}$ naik turun, akan menghambat kerja enzim dan mencegah perkembangbiakan mikroorganisme.

\section{Peningkatan Nutrien Esensial}

Mikroorganisme memounyai kebutuhan nutrien yang berbeda-beda, karena itu pengikatan nutrien tertentu akan mempengaruhi organisme yang berbeda pula. Apabila nutrien tersebut diikat, akan lebih sedikit berpengaruh 
pada organisme dibandingkan dengan organisme lain yang memerlukan nutrien tersebut dalam jumlah banyak.'

Berdasarkan sifak toksikitas selektifnya, senyawa antimikroba digolongkan menjadi dua kelompok yaitu antimikroba yang bersifat bakteriostatik yang bekerja dengan cara menghambat pertumbuhan populasi bakteri tanpa mematikan, sedangkan bakteri yang bersifat bakterisida dengan cara membunuh bakterinya (Jawetz et al, 1996: 213). Efektivitas penggunaan suatu senyawa antimikroba didalam bahan pangan sangat tergantung pada kondisi produk pangan seperti pH (keasaman), polaritas, komposisi nutrisi didalam bahan pangan, juga tergantung pada faktor lainnya seperti kondisi suhu dan proses pengolahan, pengemasan serta penanganan pasca pengolahan

\section{Antimikroba Alami}

Beberapa pengawet alami yang berasal dari tumbuhan umumnya bersifat halal. Merujuk surat al Baqaroh ayat 172, Allah menghalalkan kita mnegkonsusmsi segala sesuatu yang diciptakannNya, kecuali yang diharmkanNya kepada kita. Banyak sekali kandungan senyawa kimia yang terkandung dalam tumbuhan atau hewan yang memounyai sifat sebgai pengawet, antara lain bawang putih, jahe, belimbing wuluh, daun jati dan lain-lain. Secara tradisioanl umumnya masayarakat telah menggunakan bahan-bahan alam ini sebagai pengawet.

Pengawet kimia selama ini umum digunakan sebagai bahan tambahan untuk membatasi jumlah mikroorganisme yang hidup didalam pangan. Bahaya negatif yang disebabkan karena penggunaan senyawa kimia secara berlebih dalam makanan membuat konsumen sedikit kawatir terhadap bahaya keracunan yang disebabkan penggunaan bahan kimia tersebut. Hal ini memaksa industri pangan untuk menghindari penggunaan pengawet kimia pada produknya,serta mencari alternatif lain yang lebih alami untuk mempertahankan atau memperpanjang umur simpan produk. Kecenderungan back to nature mengoptimalkan bahan-bahan alam untuk 
digunakan sebagai pengawet makanan alami. Bahan-bahan alam ini secara alamia, akan lebih mudah diterima oleh tubuh.

Sejak lama telah disadari, bahwa banyak bahan alam memiliki aktivitas menghambat mikroba, yang disebabkan oleh komporın tertentu yang ada didalamnya. Masyarakat Mesir kuno sekitar tahun 1550 SM telah menerapkan penggunaan pengawet alami dengan menggunakan rempah sebagai pengawet pangan dan pembalsem mumi.

Penelitian mengenai potensi pengawetalami yang dikembangkan dari tanaman rempah (seperti jahe, kayu manis, andaliman, daun salam dan sebagainya) maupun dari produk hewani (seperti lisozim, laktoperoksidase, kitosan dan sebagainya) sendiri sebenarnya telah banyak dilakukan di berbagai perguruan tinggi di Indonesia. Beberapa hasil penelitian in vitro terhadap efek anti bakteri, bahan alam yang dilakukan antara lain dari tanaman Belimbing Wuluh (Averrhoa bilimbi L.). Tanaman belimbing wuluh ini baik daun, buah bahkan batangnya mempunyai manfaat dan khasia, batang belimbing wuluh (Faradisa, 2008) dan buah belimbing wuluh (Latifah, 2008), secara laboratories mempunyai potensi sebagai antimikroba.

\section{Batang Belimbing Wuluh}

Senyawa saponin yang terdapat dalam batang Belimbing Wuluh di duga mempunyai potensi sebagai antimikroba. Pada penelitian ini ekstraksi dengan metode ekstraksi bertahap dilakukan sebanyak dua kali. Kadar ekstrak kasar saponin yang diperolelı 0,35 \% b/b. Ekstrak saponin dapat menghambat pertumbuhan bakteri S. aureus pada konsentrasi 200 $\mathrm{mg} / \mathrm{mL}$ dan terus meningkat sampai pada konsentrasi $800 \mathrm{mg} / \mathrm{mL}$. Akan tetapi efektivitas ekstrak saponin hasil isolasi sebagai antimikroba terhadap S. aureus memberikan zona hambat yang lebih kecil dibandingkan zona hambat antibiotik standar (pinisilin), jadi treatmen ekstrak kasar saponin pada penelitian ini termasuk dalam kategori resisten dalam menghambat pertumbuhan bakteri s. aureus. Zona hambatan terhadap E. coli ditunjukkan pada konsentrasi $300 \mathrm{mg} / \mathrm{mL}$. Pada konsentrasi $300 \mathrm{mg} / \mathrm{mL}$ dan terus 
mengalami peningkatan zona hambat sampai konsentrasi $1000 \mathrm{mg} / \mathrm{mL}$. Akan tetapi efektivitas ekstrak saponin hasil isolasi memberikan zona hambat yang lebih kecil dibandingkan zona hambat antibiotik standar (streptomycin), jadi treatmen ektrak kasar saponin pada penelitian ini termasuk dalam kategori resisten dalam menghambat pertumbuhan bakteri E. coli (Faradisa, 2008).

\section{Buah Belimbing Wuluh}

Ekstrak etanol dari buah belimbing wuluh, menunjukkan uji positif pada pengujian flavonoid dan terpenoid. Senyawa flavonoid dan terpenoid diduga bersifat aktif sebagai antimikroba. Ekstrak kasar buah belimbing wuluh masih bersifat efektif sebagai antibakteri terhadap bakteri S. aureus dan E. coli, namun ekstrak etanol memebrikan zona hambat yang lebih kecil jika dibandingkan dengan zona hambat antibiotik standar pinnisilin. diketahui konsentrasi ekstrak 300, 350, 400 dan $450 \mathrm{mg} / \mathrm{mL}$ berpengaruh sangat nyata $(p<0,01)$ di antara konsentrasi lain (Latifah 2008).

Hasil penelitian yang dilakukkan oleh para peneliti, umumnya menunjukkan bahwa secara in vitro beberapa tanaman mempunyai potensi menjadi antimikroba. Penggunaan bahan alam mempunyai potensi yang sangat besar dan relatif aman terhadap tubuh, Akan tetapi aplikasi penggunaan ke dalam bahan pangan sebagai pengawet alami yang dapat diproduksi secara komersial dan teraplikasikan ke dalam bahan panagn perlu penelitian lebih lanjut. Ini menjadi tantangan tersendiri bagi peneliti-peneliti khususnya di lingkungan Universitas Islam Negeri Malang.

\section{Simpulan}

Al Quran telah menyeruhkan kita untuk mengkonsumsi makanan yang bersifat halal dan toyyiban. Kebutuhan akan pangan pada dewasa ini makin meningkatkan pula teknologi pangan guna memenuhi kebutuhan konsumen yang menginginkan makanan yang segar, siap saji dan menarik. 
Untuk memenuhi tuntutan itu semua digunakan senyawa kimia sebagai bahan aditif makanan. Pemakaian senyawa kimia dalam makanan tersebut dapat menimbulkan penyakit apabila digunakan dalam jumlah berlebih. Pengoptimalan bahan-bahan alam untuk digunakan sebagai pengawet makanan alami, hendaknya lebih dikembangkan baik dalam skala penelitian laboratoris dan teraplikasikan dalam industri pangan. Bahan-bahan alam ini secara fisiologi, akan lebih mudah diterima oleh tubuh.

\section{Daftar Pustaka}

Bhreisy dan Bahreisy. 2002. Terjemahan Singat Tafsir Ibnu Katsir. Surabaya: Bina Ilmu.

Cahyadi, Wisnu. 2008. Analisis Aspek Kesehatan Bahan Tambahan Pangan. Edisi kedua. Jakarta: Bumi Aksara.

Faradisa, Maria. 2008. Uji Efektifitas Antimikroba Senyawa Saponin dari Batang Belimbing Wuluh (Averrhoa Bilimbi L.). Skripsi. Malang: UIN Malang.

Jawetz E. Adelberg EA and Melniek J. 1996. Mikrobiologi Kedokteran. Terjemahan oleh Enugroho E \& Maulana RF. Edisi ke-20. Jakarta: EGC.

Jusuf, Edy. 2009. Produk Berlabel Halal. Harian Pikiran Rakyat. Jumat 3 April 2009

Latifah, A'yunin. 2008. Uji Efektifitas Ekstrak Kasar Senyawa Antibakteri Pada Buah Belimbing Wuluh (Averrhon Bilimbi L.) Dengan Variasi Pelarut. Skripsi. Malang: UIN Maleng.

Syamsir, Elvira. 2007. Pengawet Alami Pengyanti Formalin: Adakah?. Bogor: Departemen Ilmu Pangan IPB.

Widianti, Evi. 2007. Bahan Pengawet (Preserratives). (Online). Diakses $14 \mathrm{Mei}$ 2009.

Badan Pengawasan Obat dan Makanan. (C.1ine). http://www.pom.go.id. Diakses 5 Juli 2009. 
Lembaga Pengkajian Pangan, Obat-obatan dan Kosmetik Majelis Ulama Indonesia. (Online). http://www.halalmui.org. Diakses 5 Juli 2009. 